\title{
Apresentação do Dossiê
}

Os oito textos do dossiê Religião, Cultura Material e Cultura Visual comprovam em conjunto a relevância do tema para diversas áreas dos estudos das religiões e dos estudos teológicos: estudos textuais, incluindo textos fundantes, eclesiásticos, doutrinários e históricos; estudos materiais, tanto arqueológicos como arquitetônicos, inclusive espaços públicos; estudos ritualistas, de corpos em movimentos e em relacionamentos múltiplos, com pessoas, consigo mesmo, Deus, espaços e artefatos; e, last not least, estudos visuais, contemplando logos, ornamentações, artes religiosa, litúrgica e sacra, símbolos e espaços virtuais. Tudo isso ocorre de forma descritiva, analítica ou se aprofunda na sua fundamentação epistemológica, muitas vezes ainda, de forma interdisciplinar, acrescendo, não poucas vezes, às pesquisas sobre a religião estabelecidas e consideradas consagradas novas perspectivas, representando novos desafios.

Os primeiros textos focam em contextos de textos do Primeiro Testamento. Em "The God's aesthetics: material exchanges in the theological construction of the idea of divinity in ancient Israel", explora Dr. João Batista Ribeiro Santos, professor da Escola de Teologia da Umesp e recentemente concluído o pós-doutoramento em História Antiga na Faculdade de Ciências e Letras da Universidade Estadual Paulista (Unesp), ao lado dos textos bíblicos, a relação histórica entre espaço e a imaginada presença da divindade a partir da arte ritualística dos espaços sagrados e o que ela nos diz sobre conflitos conceituais e políticos da época.

Ao mesmo período de pesquisa pertence também Dr. Silas Klein Cardoso, atualmente pós-doutorando da Universidade de Berna, Suíça. Ele nos familiariza com os desafios que os estudos materiais, no caso, arqueológicos, podem representar para a nossa compreensão dos textos fundantes: "Templos da Casa de Saul? Dissonâncias entre o registro bíblico e material”.

Vinícius Couto, doutorando na Umesp, compartilha conosco um aspecto da sua pesquisa de doutorado em andamento. Em "Entre a verdade e a heresia: representações iconográficas de Jacó Armínio como um herói reformador e perturbador da religião", lembra que disputas teológicas ocorrem, muitas vezes, por múltiplos meios, inclusive de imagens. Não é de pouco charme que 
para isso os contraentes precisavam aprender usar uma terceira linguagem, a linguagem visual. Como isso foi feito no século 17 entre os calvinistas é assunto do seu texto.

Dr. Helmut Renders, professor da Escola de Teologia e do PPG em Ciências da Religião da Umesp, apresenta um texto dentro do seu esforço principal de apresentar a cultura visual evangélica. Essa vez, foca em obras devocionais da virada do século 17 para o 18 e resgata a memória do uso de quase 500 imagens em duas obras do sacerdote anglicano Samuel Wesley. "A linguagem visual religiosa em obras de Samuel Wesley: uma breve introdução em sua escolha de artistas e alguns aspectos iconográficos" evidencia como o anglicano estava acostumado com o uso da cultura visual, a forma pelo qual ele escolhe os melhores artistas com fama nacional para produzir as gravuras dos seus livros e que uma das funções dessas imagens é "vitalizar" a relação do[a] leitor[a] com o texto bíblica.

Segue um texto escrito de mãos duplas. Lídia Kameyo Ueda-Fischer, atualmente, mestranda no PPG em Ciências da Religião, e Helmut Renders, apresentam uma pesquisa, inicialmente, desenvolvida por ela sob sua orientação. "A linguagem visual da Bíblia de Família Pictorial de Foster do ano 1890 e a articulação do afeto religioso e da sensibilidade social" nos catapulta para um texto trazido dos Estados Unidos da América para o Brasil, provavelmente, por missionários metodistas. Esse gênero das Bíblias Pictoriais de Família é um produto originário estadunidense, inaugurado pelo metodista Harper em 1848. Os autores estabelecem uma relação entre as imagens, seu criador e sua mensagem como meios de projeção e promoção de um projeto religioso social dinâmico.

Dr. David Morgan da Duke University em Durnham, NY/USA, dos Departamentos dos Estudos da Religião, da Arte e História da Arte e dos Estudos Visuais, atualmente um dos maiores especialistas na área e cofundador da renomada revista científica Material Religion, contextualiza esse gênero de Bíblias num quadro maior enquanto, introduzindo seu leitor e sua leitora à “... cultura visual do protestantismo americano no século 19". O texto é mantido em inglês e é aqui publicado com a permissão da Universidade Estadual do Pará na pessoa do coordenador do seu Programa de Pós-Graduação em Ciências da Religião, Dr. Douglas Rodrigues da Conceição, já que a versão portuguesa será em breve publicado numa publicação colaborativa entre esse programa e o Programa de Pós-Graduação em Ciências da Religião da Umesp. Agradecemos pela oportunidade e esperamos alcançar, dessa forma, um público diferenciado. 
O próximo artigo também foi escrito por duas pessoas. Dr. Vitor Chaves de Souza, professor do Programa de Pós-Graduação em Ciências da Religião da Umesp, e Ana Beatriz de Carvalho dos Santos Alexandrini, mestranda do programa e, inclusive, pesquisadora da já mencionada Bíblia Pictorial de Família de Harper, exploram em "Variações imaginárias e símbolo religioso: aproximações hermenêuticas" a sobrevivência das imagens primordiais no subconsciente bem como os valores arcaicos preservados nos símbolos culturais e fundantes das sociedades que constituem o imaginário de uma determinada cultura.

Finalmente, leva nos Dr. Márcio Luiz Fernandes, professor do Programa de Pós-Graduação em Teologia da Pontifícia Universidade Católica do Paraná, para um passado ainda presente. Em "A arte mural de Mino Cerezo Barredo no período militar brasileiro" examina algumas obras realizadas pelo artista durante o período militar e explora as respectivas relações seja com o contexto da arte sacra do século XX na América Latina, seja com a denúncia dos horrores e violências praticadas contra os grupos mais vulneráveis da sociedade brasileira no referido período, lembrando do papel humanizante e humanizadora da arte em sua dimensão libertadora.

Agradecemos pelas contribuições que mais uma vez compravam a importante desse campo de investigação com uma indicação do lançamento do primeiro livro da nossa área Ciências da Religião e Teologia plenamente dedicado aos estudos da cultura visual e material, ainda nesse ano 2020: HIGUET, Etienne Alfred; MENDONÇA, Katia; RENDERS, Helmut (orgs.). A cultura material e visual como linguagens da religião. Editora da UEPA, [2020].

Em nome dos organizadores desse dossiê,

Prof. Dr. Frederico Pieper (UFJF)

Prof. Dr. Luis Américo Silva Bonfim (UFS)

Prof. Dr. Helmut Renders (UMESP) 